\title{
Effect of SME's Managerial Ability and Executive Compensation on Firm Value
}

\author{
Won Park ${ }^{1}$ and Chunggyu Byun ${ }^{2, *}$ \\ 1 Division of Business Administration, Kyungnam University, Changwon 51767, Korea; \\ wpark@kyungnam.ac.kr \\ 2 Entrepreneurship Research Institute, Gyeongsang National University, Jinju 52725, Korea \\ * Correspondence: cgbyun@gnu.ac.kr; Tel.: +82-055-772-1512
}

check for

updates

Citation: Park, W.; Byun, C. Effect of SME's Managerial Ability and Executive Compensation on Firm Value. Sustainability 2021, 13, 11828. https://doi.org/10.3390/su132111828

Academic Editor: Wen-Hsien Tsai

Received: 30 September 2021

Accepted: 24 October 2021

Published: 26 October 2021

Publisher's Note: MDPI stays neutral with regard to jurisdictional claims in published maps and institutional affiliations.

Copyright: (c) 2021 by the authors. Licensee MDPI, Basel, Switzerland. This article is an open access article distributed under the terms and conditions of the Creative Commons Attribution (CC BY) license (https:// creativecommons.org/licenses/by/ $4.0 /)$.

\begin{abstract}
This paper analyzes the impact of the managerial ability and level of compensation on firm value in small and medium enterprises. The ability of managers is important for the sustainability and growth of small and medium enterprises because they lack awareness of resources, technology, and reputation compared to large enterprises. The managerial ability is the ability to efficiently utilize resources and choose the investment plan with the highest future net cash flows. Managerial ability is also an indicator of the level of compensation for executives. Therefore, the level of executive compensation can help a firm value or growth if it is based on managerial abilities. In addition, high executive compensation standards can be an opportunity or motivation to work hard for the wealth of companies and shareholders. We analyzed 1872 small and medium-sized companies listed on the Korean stock market to achieve the purpose of the research. We analyzed the accounting period of 6 years from 2012 to 2017. Our results have had a positive impact on firm value with executive compensation. In groups with excellent managerial skills, executive compensation has had a positive (+) impact on firm value. However, executive compensation did not have a significant impact on firm value in groups with poor managerial skills. These results validate that the CEO's role in small and medium enterprise is important and that the level of compensation for executives is important to motivate. It also suggests that executive compensation cannot affect the firm value in groups with low managerial abilities.
\end{abstract}

Keywords: small and medium enterprise (SMEs); managerial ability; executive compensation; firm value; CEO's role

\section{Introduction}

Executives make strategic decisions that are important to the operation of the enterprise and plan, direct, and control the enterprise [1]. With the changing market environment of enterprises and the globalizing competition, managerial characteristics can be an important and decisive factor in determining the value and performance of the enterprise $[2,3]$.

Recent accounting studies have been conducted with interest in managerial abilities among managerial characteristics [4-7]. Representatively, Demerjian et al. [8,9] measured managerial abilities based on the Data Envelopment Analysis (DEA) method. Executives with excellent abilities have excellent future predictive abilities, a high understanding of business, and can accurately analyze the external economic environment. Therefore, capable executives are expected to adopt investments that maximize the net present value of a firm, which will have a positive impact on the growth, sustainability, future performance, and firm value.

In addition, managerial ability is an important factor in determining executive compensation. In terms of managerial ability hypothesis, a high level of executive compensation can secure executives with competence and reputation. High compensation to executives can serve as motivation and inducement for operating activities that solve the agency problem and maximize shareholder's wealth. Consequently, the executive compensation 
system resulting from performance was considered to increase firm value as well as efficient investment by the firm [10]. However, Korea's executive compensation is not due to managerial ability or performance generation. Therefore, executive compensation can make it difficult for CEOs to demonstrate their abilities and they lack relevance to management performance [11]. In addition, even if the criteria for measuring compensation are performance, the performance is focused on short-term performance [12]. In addition, executive compensation can lead to inefficient allocation because executive compensation is focused on quantitative performance such as sales growth [13]. The criteria and indicators in determining the level of compensation for executives in Korea are not clearly determined. Kim et al. [14] proposed that these limitations could hinder corporate transparency and add to agency problems rather than contribute to the development or growth of a company.

Therefore, verifying the impact of executive compensation on firm value is an important issue, and small and medium enterprises that lack resources need to verify that executive compensation creates firm value, not opportunistic actions. It should also be verified that executive compensation increases the firm value when attributed to managerial abilities.

Prior studies of executive compensation report that it has a positive impact on managerial performance or firm value because executive compensation generally reduces opportunistic behavior and solves agency problems. Rose and Shepard [10] proposed that if the level of executive compensation is high, it is possible to obtain competent and prestigious executives. If the level of compensation is high, executives can be motivated to make efficient investment decisions. Therefore, the study argued that high management compensation increases firm value. Said et al. [15] suggested that executive compensation could be an incentive to improve a company's long-term or short-term performance. However, Rose and Shepard [10] described the relationship between executive compensation and firm value from a different perspective. In terms of the managerial entrenchment hypothesis, it was explained that the executives could make efforts focused solely on his or her compensation. As a result, such actions by executives could have a negative impact on firm value. According to the managerial entrenchment hypothesis, the executives showed off his or her power and said that he or she could take high compensation. They could also cause overinvestment and agency problems.

Consequently, the outcome of executive compensation having a positive impact on firm value should be preceded by managerial abilities. We will confirm that the better the managerial ability, the more positively the executive compensation contributes to firm value. In particular, small and medium enterprises lack the ability to fund external funds or hold cash more than large enterprises.

Nevertheless, if managers of SMEs take high compensation, the financial distress phenomenon of SMEs increases. Considering this, if the high executive compensation of SMEs is attributed to their managerial abilities, we believe that the growth value or performance generation will increase their firm value. However, managerial compensation that is not attributable to managerial abilities is difficult to realize the value of cash outflow. Therefore, it is necessary to verify the relationship between executive compensation and firm value attributable to managerial abilities for small and medium enterprises.

Prior studies related to executive compensation analyzed whether executive compensation affects performance, capital costs and firm value in terms of managerial ability hypotheses or managerial entrenchment hypotheses. We expanded these prior studies to provide direct verification of managerial abilities, a prerequisite for managerial compensation to contribute positively to firm value. In addition, previous studies did not analyze only small and medium enterprise in relation to executive compensation and firm value. Unlike large companies, SMEs lack cash liquidity and are difficult to raise funds for, so corporate cash outflow is a sensitive issue. When managerial ability is an important factor in determining an executive compensation, it is a defining characteristic of increasing firm value. 
We proceed with the rest of the paper as follows. Section 2 includes prior studies and hypothesis settings, and Section 3 describes empirical models, variable measurements, and samples. Section 4 presents our empirical findings, and finally, Section 5 presents conclusions and limitations.

\section{Literature Review and Research Hypotheses}

We can explain the relationship between managerial compensation and firm value with the motivation of manager's start-up [16]. A manager's behavior, attitude, passion, and decision making are different depending on the pull and push factors of their start-up. The pull factors typically consist of independence, achievement need, and a sense of social mission. On the other hand, push factors are explained as negative situations such as manager's unemployment, job dissatisfaction, and low compensation [16]. These factors can negatively affect the value of the firm due to manager's turnover, retirement, and dissatisfaction. Among these, the manager can influence the business activities, decision making, performance, and value of the firm due to the motivation of the start-up of the manager. Gódány et al. [17] suggested the push factors as having a decisive effect on the turnover of managers. Since the manager's remuneration can be a representative push factor, if the managerial compensation is the decisive motive for starting a business and the manager's compensation is low, job turnover and negligence can occur. Therefore, as the theoretical basis on which the level of manager's compensation affects the firm value, the push factor is among the manager's start-up motives. These push factors can have a negative impact on the value, growth, performance, and sustainability of a firm when the level of compensation for managers is low. Therefore, we propose that managerial compensation is an important factor influencing the value of a firm.

Executives play an important role in not only short-term and long-term goals of companies but also in making investment decisions and securing financial stability. The characteristics of an executive can be an important factor in determining the firm value $[10,18]$. However, a system of separation of corporate ownership and management can create an agency problem, an opportunistic act that pursues the managerial rent extraction. In view of this, it is important for a firm to have an executive with superior quality. In addition, companies need compensation schemes for incentives and motivations to prevent the moral hazard of executives and perform tasks motivated [19-21].

Charles [22], Kaplan and Rauh [23], and Oh [21] mentioned that the executive compensation system is a system that secures competent executives and attracts their motivation. Lee et al. [24] argued that in order to reduce opportunistic behavior toward executive compensation, it is important to strengthen executive monitoring activities and select efficient ways to grant performance-related compensation. Determinants of executive compensation include the complexity of work, solvency, and managerial ability [25]. Gaver and Gaver [26] also saw growth, workload, and operating risk as factors determining important executive compensation. Kim [12] viewed performance, behavior, scales, personal competence, or role as important factors in determining compensation.

Kim [12] noted that executive compensation study types can be divided into three studies: compensation determinants, compensation situations or outcomes, and compensation mechanisms. Compensation mechanisms can focus on corporate governance, boards of directors, controlled markets, the general public, etc. In addition, compensation circumstances and consequences include business strategies, the possibility of growth in the R\&D market, industry, national culture, and tax systems.

Executive compensation may be a system implemented for the purpose of securing excellent executives and promoting motivation. Rose and Shepard [10] describe it as the managerial ability hypothesis or the managerial entrenchment hypothesis. First, in terms of managerial ability hypotheses, a high level of managerial ability is a result of reflecting managerial ability, and a high level of managerial ability will increase future performance and have a positive impact on firm value $[15,27,28]$. That is, for capable 
executives, it is possible to increase firm value by the efficient operation and performance generation $[29,30]$.

Song [31] emphasized the importance of executive compensation as an inducement policy that addresses the agency problem and increases firm value. Kim [12] defined the ultimate purpose of executive compensation as increasing firm value. Oh [21] suggested that executive compensation is a means of securing good executives, and it motivates and encourages shareholders to maximize their wealth and firm value. The importance of executive compensation was emphasized at a time when the inflow of professional executives from ownership executives was gradually expanding [32]. Given this, an executive compensation scheme may contribute positively to the firm value by encouraging executives to reduce shareholders and agency problems and maximize firm value.

However, according to the managerial entrenchment hypothesis, the managerial opportunistic behavior would reduce firm value. Executives can focus only on their compensation and neglect the value of the entire company. Executives who take high compensation can engage in opportunistic acts because they value their compensation rather than their businesses and will have a negative impact on firm value through overinvestment and agent issues.

Choi and Kim [33] said that the executive compensation program has limitations that make it difficult to motivate or empower executives. Executive compensation may be difficult to resolve the agent's problem due to the separation of ownership and management. However, executives have the potential for opportunistic behavior due to information asymmetry and adverse selection problems, and moral hazard can reduce firm value without doing its best. There is a limit to what all managerial efforts are provided as information, so the clear proposition of performance generation cannot be resolved. Therefore, executive compensation is determined to be short-term performance, and it is difficult to relate to the company's continuous growth and performance generation or future business. Consequently, it was suggested that executive compensation could reduce overall firm value.

Kartadjumena and Rodgers [34] examined the impact of managerial compensation on the sustainability of banks, focusing on listed banks in Indonesia. In this study, it was expected that executive compensation would have a positive effect on financial performance and financial soundness and also improve environmental issues. However, as a result of the analysis, it was found that executive compensation deteriorates financial performance or financial soundness, lowering corporate value and negatively affecting sustainability. $\mathrm{Li}$ and Thibodeau [35] examined the relationship between managerial compensation and social performance. In the analysis results, it was suggested that executives with low levels of corporate social responsibility are more likely to manipulate profits to achieve their compensation goals. Lee and Hwang [36] found that managers' incentives for earnings management were high because bank managers' compensation affects risk and financial performance, and profit level is an important factor in determining their compensation. As a result of the analysis, it was found that executive compensation has an effect on bank profit management. These results may be a factor in which managerial compensation induces profit management or negatively affects financial soundness. Therefore, research on the relationship between managerial compensation and corporate value should be approached from various perspectives.

The way to solve these agency problems should be able to induce executive compensation to maximize the future performance of the enterprise and increase shareholders wealth $[24,37,38]$. Lee [39] said that the separation of ownership and management can be a reduction in shareholder's wealth if the management aims to maximize private profits. The information asymmetry of a company is highly related to the level of compensation for executives, and the agency problem can only focus on the level of compensation for executives. It was argued that these incentives negatively affect the overall company through the performance of unbalanced investment activities by the executives. In particular, executives will distort the firm value for their own compensation [40] or cause management 
uncertainty such as profit adjustment [41,42]. Park and Lee [43] predicted that if the level of compensation for executives is high, expectations from external stakeholders were expected to increase. Therefore, executives can make unreasonable profit adjustments using the discretion of accounting method. In terms of managerial entrenchment hypotheses, executive compensation can be attributed to distortion of firm performance, increased management uncertainty, or reduced firm value due to agency problems. Executive compensation can be established as the following null hypothesis for its relationship to firm value:

Hypothesis $\mathbf{1}$ (H1). Executive compensation levels are positively related to firm value.

Katz et al. [5] viewed firm's managerial ability as a major intangible resource that generates future performance or influences firm value. In the study of Finkelstein and Hamrick [44], the management is responsible for the performance of the entire enterprise, and its decisions and actions also affect the reputation of the enterprise. Therefore, empirical analysis was conducted that understands that the behaviors and roles of management have a very important meaning.

The rationale for managerial impact on firm's performance is representative of the research on manager fixed effects. Lieberman et al. [45] identified the effect of managerial characteristics on the productivity of the industry in a study centered on the automotive industry in the United States and Japan. Bertrand and Schoar [18] showed that the managerial style of the company influenced the decision making of investment and financial issues such as acquisitions and mergers. They divided managerial characteristic effects data on return on assets (ROA) into an interquartile and revealed that the level of ROA of executives in the upper (lower) ranks increased (decreased) by 3\%. Graham et al. [6] published a study that explained the executive compensation by their work experience, gender, and educational level, which are fixed effects of executives. Baik et al. [46] used media exposure, industry-adjusted gross asset return, and efficiency scores through a revised DEA to measure the managerial ability to increase the forecast direction of profit and frequency of occurrence. Park and Jung [47] examined the effect of chaebol governance on the relationship between managerial ability and stock price crash risk for listed companies in Korea. Managerial skills have been shown to reduce the likelihood of a stock crash. However, companies belonging to chaebols have shown that managerial skills increase the risk of a stock price crash. These results show that the opportunistic behavior of companies belonging to chaebols cannot act as a factor in reducing the risk of a stock price crash by managerial skills.

Managerial skills are an important factor that is related to the value or future performance of a firm. Demerjian et al. [8] noted that good executives can put in less and produce more. In other words, they measured managerial ability at the level of efficiency using DEA. Since then, many studies have measured managerial ability using that method $[2,48,49]$. In this study, based on these prior research findings, we want to use Demerjian et al. [8]'s managerial ability measurement method to verify the impact of managerial abilities on firm value.

Demerjian et al. [9] measured managerial abilities using efficiency-based indicators. These managerial abilities can affect management performance by securing, allocating, and utilizing corporate resources by predicting the future based on overall understanding of the business. Francis et al. [50] suggested that executives with excellent abilities can generate sufficient performance through general business activities of companies and that opportunistic behavior inevitably decreases due to their ability to secure cash.

Hypothesis 2 (H2). Managerial ability are positively related to firm value.

The executive compensation system of Korean companies is not as systematic as that of the U.S. and is not likely to appear as long-term performance or firm value by focusing only on short-term performance [12,21,33]. In addition, executive compensation may be linked to showing off or opportunistic behavior, which may be negative to the relationship 
between executive compensation and firm value. However, from the managerial ability hypothesis, it can be suggested that a competent executive can make investment decisions that are highly rewarding and maximize wealth with shareholders. Managerial abilities can increase future performance and firm value through qualified resource allocation, a high understanding of the business, and a good ability to forecast the future. Therefore, in this study, in groups with high managerial abilities, executive compensation and firm value can have a positive (+) effect. In groups with low managerial abilities, high managerial remuneration is difficult to have a positive impact on firm value.

In addition, if managerial compensation reflects managerial abilities, firm value will increase with it. The level of executive compensation regardless of their abilities will not be able to establish a strategy that accurately reflects proper investments, characteristics, and economic states of the company. Therefore, if the managerial ability is low, the executive compensation will have no or negative impact on the firm value.

Hypothesis 3 (H3). The higher the level of managerial ability, the more the executive remuneration is positively related to firm value.

\section{Research Design and Sample Selection}

\subsection{Empirical Models}

In this study, the following equations were organized as follows to verify the effect of managerial ability estimated by executive compensation and efficiency on firm value:

$$
\begin{gathered}
M V_{t}=a_{0}+a_{1} \text { COMP }_{t}+a_{2} \text { Foreign }_{t}+a_{3} \text { DIV }_{t}+a_{4} I N S_{t}+a_{5} \text { CHL }_{t}+a_{6} \text { SIZE }_{t}+a_{7} \text { Growth }_{t}+ \\
a_{8} \text { Beta }_{t}+a_{9} L E V_{t}+a_{10} R O A_{t}+Y D_{t}+I D_{t}+e_{t} \\
M V_{t}=a_{0}+a_{1} M A_{t}+a_{2} \text { Foreign }_{t}+a_{3} D I V_{t}+a_{4} I N S_{t}+a_{5} \text { CHL }_{t}+a_{6} \text { SIZE }_{t}+a_{7} \text { Growth }_{t}+a_{8} \text { Beta }_{t}+ \\
a_{9} L E V_{t}+a_{10} R O A_{t}+Y D_{t}+I D_{t}+e_{t}
\end{gathered}
$$

where $M V_{t}$ represents firm value in period $\mathrm{t}$, which is equal to the closing price of the stock, as reported by KIS-VALUE. COMP $P_{t}$ represents the executive compensation amount. We measure the managerial ability $\left(M A_{t}\right)$ proxy using the efficiency controlled firm's special effects of Demerjian et al. [8]. We include foreign ownership ratio (Foreign $t_{t}$ ) as a control variable in our model (1) and (2). Foreign shareholders can influence the firm value because they monitor the firm or evaluate the stock price with professional knowledge. In addition, the dividend dummy variable $\left(D I V_{t}\right)$ included as a control variable, which was measured as 1 if dividend was paid in period $t$, and 0 otherwise. $I N S_{t}$ represents audit opinions ( 1 if the audit opinion in period $t$ is qualified, 0 if not), and $C H L_{t}$ represents cash holdings level (operating cash flows in period $\mathrm{t} /$ total assets in period $\mathrm{t}$ ). SIZE $E_{t}$ represents firm size (the natural logarithmic value of the total assets in period $t$ ), and Growth $h_{t}$ represents sales growth rate in period $t$, which is calculated by subtracting $t-1$ sales from $t$-period sales and dividing by $\mathrm{t}-1$ sales. Bet $a_{t}$ represents the risk of a firm, which is the measured systematic risk using 60-month monthly returns. $L E V_{t}$ represents the debt ratio, which is the measured total liabilities as the end of period $t$ dividing by total assets at the end of period $t$. Return on assets $\left(R O A_{t}\right)$ represents the profitability of a firm in period $\mathrm{t}$, which is calculated as the net earnings in period $t$ divided by total assets at the end of period t. $Y D_{t}$ and ID are year dummy variables and industry dummy variables, respectively. If they belong to the relevant year or industry, they are 1 , otherwise, 0 . These two dummy variables are included in model (1) and model (2) to control for year and industry.

Models (1) and (2) show that if the regression coefficient $a_{1}$ appears to be a significant positive $(+)$, the better the executive compensation or managerial ability, the more it positively contributes to the value of the firm. In addition, in this study, the following equation was added to verify the effect of manager compensation on firm value according to managerial ability: 


$$
\begin{gathered}
M V_{t}=a_{0}+a_{1} C_{1, t}+a_{2} C_{2, t}+a_{3} C_{3, t}+a_{4} \text { Foreign }_{t}+a_{5} D_{I V}+a_{6} I N S_{t}+a_{7} C H L_{t}+a_{8} \text { SIZE }_{t}+ \\
a_{9} \text { Growth }_{t}+a_{10} \text { Beta }_{t}+a_{11} L E V_{t}+a_{12} \text { ROA }_{t}+Y D_{t}+I D_{t}+e_{t}
\end{gathered}
$$

where $C M_{j, t}$ represents Managerial ability code and dummy variables based on the executive compensation median. When $j$ is equal to 1 , managerial ability is a positive measure, and managerial compensation is 1 ; otherwise, it is 0 for a sample higher than the median over time $t$. When $j$ is equal to 2 , managerial ability is a positive measure, and managerial compensation is 1 ; otherwise, it is 0 for a sample less than the median over time $t$. When $j$ is equal to 3 , the managerial ability code is 1 if it is negative and greater than the executive compensation median (if not, 0 )

In Equation (3), the regression coefficient $a_{1}$ will have a significant positive $(+)$ value if the higher the level of managerial ability and executive compensation, the higher the firm value. If the regression coefficient is greater than the regression coefficient $a_{2}$ $\left(a_{1}>2\right)$, there is a difference in firm value depending on the executive remuneration. If the regression coefficient $a_{1}$ is significantly greater than the regression coefficient $a_{3}$ $\left(a_{1}>a_{3}\right)$, it is suggested that there is a difference even if the managerial ability controls the executive remuneration.

In addition, this study seeks to verify Equation (1) by dividing it into groups with high and low managerial abilities. In addition, we included the control variables, such as the size and leverage of the firm, share ratio of foreigners, and growth. In addition, the control variables such as size, leverage, foreign ownership, and growth potential were included in the model. Scale can increase firm value by providing stability and continuous investment capacity. On the contrary, large enterprises may find it difficult to create value because their growth potential slows [51]. In addition, leverage may incur interest expense, reduce cashflow, and affect firm value because it would increase financial risk. An alternative variable for growth is sales growth rate, which means revenue growth. Profitability contributes positively to firm value. In previous studies, the foreign ownership was expected to increase firm value by strengthening the monitoring or screening function of companies and reducing opportunistic behavior of executives [52]. Dividend payout ratio is also persistent, so investors can have a positive impact on firm value by considering their continued dividend income. On the other hand, firms with high dividends may have a negative impact on firm value because they may lack cash for future investments [53]. Firm with a large amount of cash reserves would be able to increase its value because it would be able to make qualified investments to suit its strategy [54]. We included and controlled year dummy variables and industry dummy variables in the model to consider the effect of each year and industry characteristics.

\subsection{Measurement of Variables}

\subsubsection{Executive Compensation}

In this study, compensation was used as a variable for executive compensation [37,55]. The managerial ability was measured using the methods by Demerjian et al. [8], Francis et al. [50], and Choi and Yang [56]. We used the average compensation per executive, and it was scaled by taking a natural log on the compensation because of the presence of heteroscedasticity.

Although compensation for executives exists not only for monetary compensation but also for stock option, the reasons for using the compensation variable are as follows:

First, the ratio of compensation to total compensation is relatively high. Second, compensation is more effective in verifying the information power of accounting profits because the effect of earnings on compensation is greater than that of stock prices [57]. Therefore, we calculated the executive compensation as cash compensation, combining the executive salary and bonuses. In addition, variable measurements are defined as those taken natural logarithm on the compensation (salary plus bonuses) per executive. In order to control the natural increase over the year, the compensation was used to vary from the annual average value to the compensation amount of one manager of the firm. In addition, 
the compensation amount was used as the difference in compensation amount of one executive of the company from the average annual value to control the natural increase according to the year.

\subsubsection{Proxy for Managerial Ability}

The managerial ability of this study is calculated using the managerial ability measurement in two stages using the analysis method measured by Demerjian et al. [8]. Demerjian et al. [8] viewed the efficiency measure, which is important for the creation of earnings, a corporate goal, as the manager's ability. The efficiency produced by the DEA method can be attributed to firm's fixed effects. Thus, the next step eliminates the fixed effects of the firm through Tobit regression analysis. In this study, the residual eliminated the intrinsic effect was considered a measurement of managerial ability.

As a first step, the efficiency of the firm was measured using the DEA method (In this study, data envelope analysis (DEA) was conducted using software ' $R$ version 3.6.1'). Inputs (Demerjian et al. [8] used seven factors: cost of sales, selling and administrative expenses, tangible asset, good will, other intangible assets, operating release, and R\&D cost as inputs to measure corporate efficiency. In this study, factors such as goodwill, operating lease, and R\&D expenses, which are data that can only be found in some corporate data in Korea, were excluded with good will and other intangible assets as one value for intangible assets, four inputs, namely, cost of sales, selling and administrative expenses, tangible asset, and intangible assets, were adjusted and used.) to measure firm efficiency mean the cost of sales, selling and administrative expenses, tangible assets, and intangible assets that contribute to the generation of the firm revenue. Executives with high managerial abilities defined output as sales volume in line with the premise that limited resources generate maximum revenue. The following expression (4) was analyzed separately from the group of affiliated industrial firms for the year:

Step 1: DEA measurement model to measure efficiency

$$
\mathrm{FE} v \theta=\frac{\text { Sales }}{v_{1} \operatorname{SCos} t+v_{2} \operatorname{Sn} A+v_{3} \text { Tang }+v_{4} \text { Itang }}
$$

Here, FEv $\theta$ : Firm efficiency by data development analysis;

Sales: Sales;

SnA: Selling and administrative expenses;

Tang: Tangible property (=Tangible property-land-construction in progress);

Itang: Intangible property.

Step 2: Tobit regression analysis model for fixed effect control:

$$
F_{t}=a_{0}+a_{1} L_{t}+a_{2} M S_{t}+a_{3} F_{C F I}+a_{4} A g e_{t}+a_{5} B_{t}+a_{6} F_{t}+Y D_{t}+I_{t}+e_{t}
$$

Here, FE(Firm efficiency): Measurement of firm efficiency by DEA analysis method;

$\mathrm{LA}_{\mathrm{t}}$ : Natural log value of total assets;

$\mathrm{MS}_{\mathrm{t}}$ : Sales/total sales of firm in the same industry;

$\mathrm{FCFI}_{\mathrm{t}}: 1$ if surplus cash flows (operating profit- $\Delta$ operating capital-investment amount = capital expenditure) are greater than 0 , or 0 ;

Age $_{t}$ : Years of progress since company listing;

$\mathrm{BS}_{\mathrm{t}}$ : Number of business sectors;

$\mathrm{FC}_{\mathrm{t}}$ : The sum of the absolute sizes of foreign currency translation accounts (foreign currency translation gains, foreign currency translation losses, foreign exchange gains, foreign exchange losses)/sales;

$\mathrm{YD}_{\mathrm{t}}$ : Year dummy.

In two steps, the firm efficiency measured by the DEA method is a mixture of the firm's fixed factors with the managerial ability. To distinguish the efficiency of managerial abilities, Tobit regression analysis was conducted. Demerjian et al. [8] established the firm's fixed effect as "assets, market share, free cash flow, firm age, business segment and 
foreign currency accounting". We believe that competent executives control the size of the firm because they can be employed by large enterprises [58]. In addition, executives of companies with high market share and large firms can expect to negotiate more effectively than third parties while maintaining a constant managerial ability when negotiating with raw material suppliers and customers. It is also believed that control is necessary because firms' executives with enough surplus cash flows can effectively make decisions to obtain positive present value while maintaining that ability. Fourth, investment costs of a firm will vary from cycle to cycle, which is expected to affect the managerial strategy for initial investment costs and decision making, thus controlling the life of the firm since its establishment [59]. Furthermore, diversification will be difficult to allocate resources efficiently because, as industries diversify, experience in organization management requires more knowledge, and in the case of executives entering individual industries, it is likely to reduce attention to workload growth. $[60,61]$. Therefore, the model used the number of business segments to consider the degree of diversification of individual firms. Finally, the value of the foreign exchange account is measured by dividing it by total sales to consider foreign exchange transactions. Companies affected by exchange rate fluctuations will face complex and diverse decisions due to various environments.

It can be said that a company with a higher percentage of the sum value of the absolute size of the account of foreign currency translation gain and loss, gain and loss on foreign currency transactions accounts in the total sales of the income statement is more affected by the exchange rate. Consequently, the model including these factors was constructed as shown in Equation (5), and the residuals estimated in Equation (5) were used as an alternative measurement of the managerial ability.

\subsubsection{Proxy for Firm Value}

In order to demonstrate the impact of managerial ability and executive compensation on their relationship with firm value, the firm value was measured as follows:

$$
M V_{t}=\frac{\text { Market capitalization of common stock at the end of the period }}{\text { Total assets at the end of period } t-1}
$$

\subsection{Samples and Data}

We collected financial and stock price data using KIS-VALUE D/B of TS 2000 of Korean listed corporations. It was collected for non-financial businesses among the settlement listed in December. The sampling period was from 2011 to 2017. In a database that provides executive compensation system levels, they provided data from 2011, so we chose that period. For managerial abilities, firms with fewer than 15 industrial samples per year were excluded. In addition, a total of 1872 samples were used, excluding samples that were outside the 6 standard deviation, as shown in Table 1, because errors in the results could be increased due to outliers.

Table 1. Selection process of sample companies.

\begin{tabular}{cc}
\hline Sample Selection & Firm-Year Count \\
\hline Small and medium enterprise listed in non-financial industries (2011-2017) & 5251 \\
\hline Same year-samples of less than 15 companies in the industry & $(2219)$ \\
\hline Other variable measurement data insufficient samples & $(1069)$ \\
\hline Removing extremity & $(91)$ \\
\hline Final sample & 1872 \\
\hline
\end{tabular}

\section{Empirical Analysis Results}

\subsection{Descriptive Statistics and Correlation Analysis}

We conducted a verification of the impact of managerial abilities and managerial compensation on the relationship with firm value. It also presented the consequences of 
the impact in major variables, executive compensation, and managerial capabilities on the relationship with firm value.

An analysis of the descriptive statistics of the major variables was conducted, and the results are presented in Table 2 . In Table 2, the average managerial ability is 0.002 , and the average executive compensation is 18.935 . The average scale was 26.676 , the leverage was 0.422 , and the sales growth rate, an alternative measurement of growth, was 0.031 . Dividend payers accounted for 71 percent of the current term and 8.845 per cent on average for the foreign ownership ratio. The variables of audit opinion and beta and cash holding levels averaged $0.998,0.783$, and 0.054 , respectively.

Table 2. Descriptive statistics.

\begin{tabular}{|c|c|c|c|c|c|}
\hline Variable & Average & Std. Dev. & Median & Minimum & Maximum \\
\hline$M V_{t}$ & 0.641 & 0.506 & 0.492 & 0.118 & 2.476 \\
\hline$C O M P_{t}$ & 18.935 & 0.759 & 18.872 & 17.363 & 21.017 \\
\hline$M A_{t}$ & 0.002 & 0.076 & 0.008 & -0.180 & 0.220 \\
\hline Foreign $_{t}$ & 8.845 & 12.596 & 3.670 & 0.000 & 64.465 \\
\hline$D I V_{t}$ & 0.710 & 0.454 & 1.000 & 0.000 & 1.000 \\
\hline$I N S_{t}$ & 0.998 & 0.046 & 1.000 & 1.000 & 1.000 \\
\hline $\mathrm{CH} L_{t}$ & 0.054 & 0.056 & 0.036 & 0.000 & 0.253 \\
\hline$S I Z E_{t}$ & 26.676 & 1.391 & 26.416 & 24.288 & 30.915 \\
\hline Growth & 0.031 & 0.207 & 0.020 & -0.434 & 0.695 \\
\hline Bet $a_{t}$ & 0.783 & 0.508 & 0.739 & -0.130 & 1.810 \\
\hline$L E V_{t}$ & 0.422 & 0.192 & 0.415 & 0.069 & 0.869 \\
\hline$R O A_{t}$ & 0.025 & 0.075 & 0.027 & -0.232 & 0.167 \\
\hline
\end{tabular}

Note: Variables definition; $M V_{t}$ : Firm value [ $\frac{\text { Market capitalization of common stock at the end of the period }}{\text { Total assets at the end of period } t-1}$; $M A_{t}$ : Managerial ability index in period $\mathfrak{t}$ (Demerjian et al. [8]); $C O M P_{t}$ : Executive compensation natural log value; Foreign $n_{t}$ : Foreign ownership ratio in period $\mathrm{t}$; $D I V_{t}$ : Dividend payout in period $\mathrm{t}(1$ if period $\mathrm{t}$ dividend is executed, if not, 0$)$; $I N S_{t}$ : Audit opinions in period $\mathrm{t}(1$ if period $\mathrm{t}$ dividend is executed, if not, 0 ); CHLt: The level of cash holdings in period $t$ (operating cash flow in period $t / g r o s s$ assets in period $t$ ); $S I Z E_{t}$ Firm size in period $\mathrm{t}$ (the natural logarithmic value of the gross asset in period $\mathrm{t}$ ); Growth $\mathrm{f}_{t}$ : Growth rate of sales in period $\mathrm{t}\left[\frac{(\text { sales in period } \mathrm{t})-(\text { sales in period } t-1)}{\text { sales in period } t-1}\right]$; Beta $a_{t}$ : Systematic risk using 60-month monthly returns; $L E V_{t}$ : Leverage in period $t\left[\frac{\text { total leverage at the end of period } t}{\text { total assets at the end of period } t}\right] ; R O A_{t}$ : Return on assets in period $\mathrm{t}\left[\frac{\text { net earnings in period } t}{\text { Average of total assets at the end of period } t \text { and } t-1}\right] ; Y D_{t}$ : Year dummy variable in period $\mathrm{t} ; I D_{t}$ : Industry dummy variable in period.

In this study, we analyzed the correlations of the key variables, and the results are presented in Table 3. First, executive compensation and firm value were shown as significant positive $(+)$ relationships $(r=0.155, p=0.000)$, and managerial abilities also showed significant positive $(+)$ relationships $(\mathrm{r}=0.189, p=0.000)$ to firm value. In addition, growth potential, foreign ownership ratio, $\mathrm{ROA}$, and cash holding level all showed a significant positive $(+)$ relationship with firm value, and the leverage $(\mathrm{r}=-0.322, p=0.000)$ was a significant negative $(-)$ relationship to firm value. 
Table 3. Correlation between the variables.

\begin{tabular}{|c|c|c|c|c|c|c|c|c|c|c|c|}
\hline & $M V_{t}$ & $C O M P_{t}$ & $M A_{t}$ & Foreign $_{t}$ & $D I V_{t}$ & $I N S_{t}$ & $\mathrm{CHL}_{t}$ & $S I Z E_{t}$ & Growth $_{t}$ & Beta $_{t}$ & $L E V_{t}$ \\
\hline$C O M P_{t}$ & $\begin{array}{l}0.155^{* *} \\
(0.000)\end{array}$ & & & & & & & & & & \\
\hline$M A_{t}$ & $\begin{array}{l}0.189 * * \\
(0.000)\end{array}$ & $\begin{array}{c}0.103 * * \\
(0.000)\end{array}$ & & & & & & & & & \\
\hline Foreign $_{t}$ & $\begin{array}{l}0.192 * * \\
(0.000)\end{array}$ & $\begin{array}{l}0.281^{* *} \\
(0.000)\end{array}$ & $\begin{array}{l}0.079 * * \\
(0.001)\end{array}$ & & & & & & & & \\
\hline$D I V_{t}$ & $\begin{array}{l}0.118 * * \\
(0.000)\end{array}$ & $\begin{array}{l}0.290 * * \\
(0.000)\end{array}$ & $\begin{array}{l}0.048 * \\
(0.037)\end{array}$ & $\begin{array}{l}0.171^{* *} \\
(0.000)\end{array}$ & & & & & & & \\
\hline$I N S_{t}$ & $\begin{array}{c}0.024 \\
(0.291)\end{array}$ & $\begin{array}{l}0.056 * \\
(0.016)\end{array}$ & $\begin{array}{c}0.020 \\
(0.397)\end{array}$ & $\begin{array}{c}0.018 \\
(0.433)\end{array}$ & $\begin{array}{l}0.047 * \\
(0.042)\end{array}$ & & & & & & \\
\hline $\mathrm{CH}_{t}$ & $\begin{array}{l}0.208 * * \\
(0.000)\end{array}$ & $\begin{array}{l}-0.004 \\
(0.848)\end{array}$ & $\begin{array}{l}0.063 * * \\
(0.006)\end{array}$ & $\begin{array}{l}0.163 * * \\
(0.000)\end{array}$ & $\begin{array}{c}0.025 \\
(0.286)\end{array}$ & $\begin{array}{c}0.001 \\
(0.975)\end{array}$ & & & & & \\
\hline$S I Z E_{t}$ & $\begin{array}{l}-0.002 \\
(0.947)\end{array}$ & $\begin{array}{c}0.595 * * \\
(0.000)\end{array}$ & $\begin{array}{l}0.061 * * \\
(0.008)\end{array}$ & $\begin{array}{l}0.435 * * \\
(0.000)\end{array}$ & $\begin{array}{l}0.205 * * \\
(0.000)\end{array}$ & $\begin{array}{c}0.031 \\
(0.185)\end{array}$ & $\begin{array}{c}-\overline{-} \\
0.048 \\
*(0.039)\end{array}$ & & & & \\
\hline Growth $_{t}$ & $\begin{array}{l}0.136 \text { ** } \\
(0.000)\end{array}$ & $\begin{array}{c}0.034 \\
(0.141)\end{array}$ & $\begin{array}{l}0.106^{* *} \\
(0.000)\end{array}$ & $\begin{array}{c}0.019 \\
(0.413)\end{array}$ & $\begin{array}{c}0.041 \\
(0.075)\end{array}$ & $\begin{array}{l}0.047 * \\
(0.042)\end{array}$ & $\begin{array}{c}0.017 \\
(0.454)\end{array}$ & $\begin{array}{c}0.030 \\
(0.189)\end{array}$ & & & \\
\hline Beta $_{t}$ & $\begin{array}{c}0.025 \\
(0.279)\end{array}$ & $\begin{array}{l}0.104^{* *} \\
(0.000)\end{array}$ & $\begin{array}{c}0.034 \\
(0.142)\end{array}$ & $\begin{array}{c}0.023 \\
(0.317)\end{array}$ & $\begin{array}{c}-0.094^{* *} \\
(0.000)\end{array}$ & $\begin{array}{l}-0.012 \\
(0.609)\end{array}$ & $\begin{array}{l}-0.002 \\
(0.925)\end{array}$ & $\begin{array}{l}0.183 \text { ** } \\
(0.000)\end{array}$ & $\begin{array}{l}-0.008 \\
(0.719)\end{array}$ & & \\
\hline$L E V_{t}$ & $\begin{array}{c}-0.322 \text { ** } \\
(0.000)\end{array}$ & $\begin{array}{l}-0.005 \\
(0.830)\end{array}$ & $\begin{array}{l}-0.040 \\
(0.085)\end{array}$ & $\begin{array}{c}-0.152 \text { ** } \\
(0.000)\end{array}$ & $\begin{array}{c}-0.326 \text { ** } \\
(0.000)\end{array}$ & $\begin{array}{c}-0.095 \text { ** } \\
(0.000)\end{array}$ & $\begin{array}{c}-0.226 \text { ** } \\
(0.000)\end{array}$ & $\begin{array}{l}0.158 * * \\
(0.000)\end{array}$ & $\begin{array}{l}0.078 * * \\
(0.001)\end{array}$ & $\begin{array}{c}0.188 * * \\
(0.000)\end{array}$ & \\
\hline$R O A_{t}$ & $\begin{array}{c}0.254 \text { ** } \\
0.000)\end{array}$ & $\begin{array}{l}0.183^{* *} \\
(0.000)\end{array}$ & $\begin{array}{l}0.135 \text { ** } \\
(0.000)\end{array}$ & $\begin{array}{l}0.129 * * \\
(0.000)\end{array}$ & $\begin{array}{l}0.372 * * \\
(0.000)\end{array}$ & $\begin{array}{l}0.153 \text { ** } \\
(0.000)\end{array}$ & $\begin{array}{l}0.073^{* *} \\
(0.002)\end{array}$ & $\begin{array}{l}0.164 \text { ** } \\
(0.000)\end{array}$ & $\begin{array}{l}0.156^{* *} \\
(0.000)\end{array}$ & $\begin{array}{l}-0.044 \\
(0.058)\end{array}$ & $\begin{array}{c}-0.291 \text { ** } \\
(0.000)\end{array}$ \\
\hline
\end{tabular}

Note: The table presents Pearson correlations. The value of $(\mathrm{)})$ is $p$-value (two-tailed test). ${ }^{*}$ and ${ }^{* *}$ indicate statistical significance at $10 \%$ and $5 \%$ respectively.

In Table 3 above, if the correlation coefficient between explanatory variables is high, multicollinearity problems may occur in multiple regression analysis for hypothesis testing. Therefore, we compensated for this problem by presenting the maximum value of VIF in the table showing the results of each multiple regression analysis.

\subsection{Regression Results}

We analyzed the impact of executive compensation and managerial abilities on firm value and presented the results in Table 4.

Table 4. The impact of managerial compensation (or ability) on firm value.

\begin{tabular}{|c|c|c|c|}
\hline \multicolumn{3}{|c|}{$\begin{array}{c}M V_{t}=a_{0}+a_{1} \text { COMP }_{t}+a_{2} \text { Foreign }_{t}+a_{3} D I V_{t}+a_{4} I N S_{t}+a_{5} C_{1} L_{t}+a_{6} \text { SIZE }_{t}+ \\
a_{7} \text { Growth }_{t}+a_{8} \text { Beta }_{t}+a_{9} L E V_{t}+a_{10} \text { ROA }_{t}+Y D_{t}+I D_{t}+e_{t} t \\
M V_{t}=a_{0}+a_{1} M A_{t}+a_{2} \text { Foreign }_{t}+a_{3} D I V_{t}+a_{4} I N S_{t}+a_{5} C H L_{t}+a_{6} \text { SIZE }_{t}+a_{7} \text { Growth }_{t}+ \\
a_{8} \text { Beta }_{t}+a_{9} L E V_{t}+a_{10} R O A_{t}+Y D_{t}+I D_{t}+e_{t}\end{array}$} & $\begin{array}{l}(1) \\
(2)\end{array}$ \\
\hline Variable & ai (t-Value) & ai (t-Value) & \\
\hline$C O M P_{t}$ & $0.109(6.553)^{* * *}$ & - & \\
\hline$M A_{t}$ & - & $0.853(6.434)^{* * *}$ & \\
\hline Foreign $_{t}$ & $0.005(5.688)^{* * *}$ & $0.005(5.367)^{* * *}$ & \\
\hline$D I V_{t}$ & $-0.095(-3.685)^{* * *}$ & $-0.068(-2.673) * * *$ & \\
\hline$I N S_{t}$ & $-0.409(-1.907)^{*}$ & $-0.344(-1.605)$ & \\
\hline $\mathrm{CHL}_{t}$ & $0.774(4.142)^{* * *}$ & $0.741(3.966)^{* * *}$ & \\
\hline$S I Z E_{t}$ & $-0.037(-3.618)^{* * *}$ & $-0.004(-0.467)$ & \\
\hline Growth & $0.359(7.303)^{* * *}$ & $0.344(6.987)^{* * *}$ & \\
\hline Beta $_{t}$ & $0.072(3.425)^{* * *}$ & $0.071(3.375)^{* * *}$ & \\
\hline$L E V_{t}$ & $-0.566(-9.223)^{* * *}$ & $-0.567(-9.239) * * *$ & \\
\hline$R O A_{t}$ & $1.125(7.493)^{* * *}$ & $1.049(6.946) * * *$ & \\
\hline Adj. $R^{2}(N)$, VIF Max. & $0.309(1872), 2.135$ & 0.309 (1872), 1.582 & \\
\hline
\end{tabular}

Note: This table reports the impact of managerial compensation (or ability) on firm value. ${ }^{*}$ and ${ }^{* * *}$ indicate statistical significance at $10 \%$ and $1 \%$, respectively 
In Table 4, the relationship between executive compensation and firm value has a significant positive $(+)$ correlation. Executive compensation can be attributed to the motivation of management to make decisions for shareholders' wealth and contribute to current and future performance [15]. Equation (1b) also confirms that the regression coefficient $a_{1}$ is a significant positive (+) relationship, which means that managerial ability positively contributes to the value of the firm $\left(a_{1}=0.853, \mathrm{t}=6.434, p=0.000\right)$. Managerial ability has been identified to be closely related to the economic value of a company. If the managerial ability is high, the manager has a very high understanding of the technology and trends of industrial changes in the industry, and it is possible for them to predict demand for products. This allows them to choose investments that can yield high returns on investment and to predict the efficiency of human resource management [62]. In addition, ROA, foreign ownership, cash holding level, and sales volume growth rate showed a positive (+) impact on firm value, similar to previous research results [53,63-65]. The leverage shown to have a negative impact on firm value, which increases interest costs corresponding to ongoing costs, which are negative to future performance, but increases in financial risk, have a negative impact on firm value.

In this study, the following analyses were conducted to verify the impact of managerial abilities on executive compensation and firm value, and the results were as follows.

In Table 5, the relevance of firm value to the matrix of managerial abilities and compensation. Empirical analysis showed that the regression coefficient $a_{1}$ of variable with high managerial abilities and executive compensation levels were significantly positive $(+)$. Groups with both managerial abilities and remuneration have higher firm value than others. Groups with excellent managerial abilities but low executive compensation levels have a disproportionate impact on firm value. In addition, groups with low managerial abilities but high executive compensation levels have a disproportionate impact on firm value. These results may suggest that even if the managerial ability is good, the compensation scheme does not positively contribute to firm value if it does not fit the ability. It also showed that even if the level of compensation for executives is high, it is difficult to connect to firm value without managerial abilities. These differences were found to be significant within the regression coefficients $\mathrm{a}_{1}$ and $\mathrm{a}_{2}, \mathrm{a}_{3}$, and significance levels of $1 \%$.

Table 5. The relevance of firm value to the matrix of managerial abilities and compensation.

\begin{tabular}{cc}
\hline$M V_{t}=a_{0}+a_{1} C M_{1, t}+a_{2} C_{2, t}+a_{3} C M_{3, t}+a_{4}$ Foreign $_{t}+a_{5} D I V_{t}+a_{6} I N S_{t}+a_{7} C H L_{t}+a_{8} S I Z E_{t}+$ \\
$a_{9}$ Growth $_{t}+a_{10}$ Beta $_{t}+a_{11} L E V_{t}+a_{12} R O A_{t}+Y D_{t}+I D_{t}+e_{t}$ \\
\hline Variable & $\mathbf{a}_{\mathbf{i}}$ (t Value) \\
\hline$C M_{1, t}$ & $0.231(7.896)^{* * *}$ \\
\hline$C M_{2, t}$ & $0.037(1.367)$ \\
\hline$C M_{3, t}$ & $0.005(1.502)$ \\
\hline Foreignt & $0.005(5.318)^{* * *}$ \\
\hline$D I V_{t}$ & $-0.078(-3.077)^{* * *}$ \\
\hline$I N S_{t}$ & $-0.356(-1.676)^{*}$ \\
\hline$C H L_{t}$ & $0.740(3.992)^{* * *}$ \\
\hline$S I Z E_{t}$ & $-0.024(-2.547)^{* * *}$ \\
\hline$G r o w t h_{t}$ & $0.344(7.036)^{* * *}$ \\
\hline Beta & $0.072(3.423)^{* * *}$ \\
\hline$L E V_{t}$ & $-0.545(-8.943)^{* * *}$ \\
\hline$R O A_{t}$ & $1.044(6.975)^{* * *}$ \\
\hline Adj. $R^{2}(\mathrm{~N})$, VIF Max. & $0.321(1872), 1.596$ \\
\hline
\end{tabular}

Note: This table reports the relevance of firm value to the matrix of managerial abilities and compensation. ${ }^{*}$ and $* * *$ indicate statistical significance at $10 \%$ and $1 \%$, respectively.

In this study, Equation (1a) was analyzed by separating managerial abilities into positive and negative groups. Managerial compensation has been shown to have a significant positive (+) effect on firm value only in groups with positive managerial abilities 
$\left(a_{1}=0.161, t=6.457, p=0.000\right)$. However, in groups with negative managerial abilities, the level of executive compensation has been shown to be non-significant to firm value $\left(a_{1}=0.024, \mathrm{t}=1.159, p=0.247\right)$.

In Table 6, both managerial remuneration and leading strategies contributed positively to firm value in groups with zero or higher managerial ability measurement. Defensive strategies have been shown to have significant negative effects on firm value. In the variables of executive compensation and leading management strategy interaction, the group with excellent managerial ability showed a significant positive $(+)$ effect. This means that among management strategies, executive compensation has increased firm value for companies pursuing leading strategies. For defensive strategies, it is not significant, similar to the results in Table 6. If the measurement of managerial abilities classified as a group with lower managerial abilities was less than zero, the relationship between executive compensation, leading strategy and firm value was not significant, nor were the leading strategy variables at the level of executive compensation. That is, it was difficult to verify the relationship between leading strategy and firm value among managerial strategies in groups with low managerial abilities. The impact of executive compensation on the relationship between managerial strategy and firm value could not be identified. However, in the case of defensive strategies, regardless of managerial abilities, it is likely that riskavoidance factors and underinvestment tendencies will reduce expectations of excess profit generation and that will have a negative impact on firm value, such as whether the industry is saturated or declining.

Table 6. Differences in the relevance of executive compensation and firm value between groups with high and low managerial abilities.

\begin{tabular}{|c|c|c|}
\hline \multicolumn{3}{|c|}{$\begin{array}{c}M V_{t}=a_{0}+a_{1} \text { COMP }_{t}+a_{2} \text { Foreign }_{t}+a_{3} D I V_{t}+a_{4} I N S_{t}+a_{5} \text { CHL } L_{t}+a_{6} \text { SIZE }_{t}+a_{7} \text { Growt }_{t} \\
+a_{8} \text { Bet }_{t}+a_{9} L E V_{t}+a_{10} R O A_{t}+Y D_{t}+I D_{t}+e_{t}\end{array}$} \\
\hline \multirow{2}{*}{ Variable } & $M A_{t} \geq 0$ & $M A_{t}<0$ \\
\hline & $a_{i}$ (t Value) & $a_{i}(t$ Value) \\
\hline$C O M P_{t}$ & $0.161(6.457)^{* * *}$ & $0.024(1.159)$ \\
\hline Foreign $_{t}$ & $0.005(3.324)^{* * *}$ & $0.004(3.584) * * *$ \\
\hline$D I V_{t}$ & $-0.102(-2.681)^{* * *}$ & $-0.051(-1.709) *$ \\
\hline$I N S_{t}$ & $-0.566(-1.191)$ & $-0.370(-1.505)$ \\
\hline $\mathrm{CH} L_{t}$ & $0.931(3.511)^{* * *}$ & $0.420(1.675) *$ \\
\hline$S I Z E_{t}$ & $-0.032(-2.139)^{* *}$ & $-0.040(-3.043)^{* * *}$ \\
\hline Growth $_{t}$ & $0.324(4.818)^{* * *}$ & $0.358(5.076)^{* * *}$ \\
\hline Beta $_{t}$ & $0.053(1.916) *$ & $0.105(3.278) * * *$ \\
\hline$L E V_{t}$ & $-0.676(-7.520)^{* * *}$ & $-0.424(-5.424)^{* * *}$ \\
\hline$R O A_{t}$ & $0.977(4.831)^{* * *}$ & $1.167(5.341)^{* * *}$ \\
\hline Adj. $R^{2}(N)$, VIF Max. & 0.333 (1038), 2.301 & $0.256(834), 2.125$ \\
\hline
\end{tabular}

Note: This table reports differences in the relevance of executive compensation and firm value between groups with high and low managerial abilities the impact of managerial compensation (or ability) on firm value. *,$* *$, and ${ }^{* * *}$ indicate statistical significance at $10 \%, 5 \%$, and $1 \%$, respectively.

\section{Discussion}

We have verified the impact of managerial abilities and compensation on firm value. The topic of this study has been conducted from a variety of perspectives in accounting $[2,5,8]$. We extended the results of the preceding study to verify the impact of managerial abilities on the relationship between executive compensation and firm value. Compensation given to executives needs to be grounded. It was suggested that executive compensation could contribute positively to firm value if the rationale was attributed to managerial abilities. In particular, small- and medium-sized companies lack resources, technology, and abilities 
compared to large companies. Small and medium enterprises have fewer types and numbers of stakeholders than larger enterprises. Therefore, SMEs can be closed and are likely to develop opportunistic acts or agency problems. When applying this situation, the executive compensation of SMEs can negatively affect the value of the company. However, the level of executive compensation also contributes positively to the firm value of SMEs. However, executive compensation without managerial abilities does not affect firm value. Therefore, we would like to propose that for the growth and development of small and medium enterprises, executive compensation should be measured on the basis of abilities.

The empirical analysis results are as follows: First, executive compensation for SMEs had a positive impact on firm value. A high level of executive compensation means an increase in firm value due to the motivation of the executive to perform their operating activities diligently.

Second, managerial abilities had a significant positive impact on firm value. Empirical analysis showed that the higher the managerial ability, the higher the firm value.

Finally, in groups with high levels of managerial ability, executive compensation has been shown to have a significant positive $(+)$ effect on firm value.

It can be suggested that managerial ability is an important background for future growth and the sustainability of small and medium enterprises that lack resources. It shows that when managerial remuneration is given due to managerial ability, the manager can do his/her best for the development and growth of the enterprise at the same time as motivating the work. We excluded stock compensation from the way in which managerial compensation is measured. This is because executives can own shares of the firm, which can lead to differences in empirical analysis results if they include share compensation.

The limitations of this study are as follows. First, we analyzed managerial compensation only for cash compensation. However, some studies have suggested that the relationship between manager compensation and corporate value may be high in a stock-linked system. Therefore, as suggested in previous studies in this field, the scope of compensation for managers is proposed. Second, we used the research method of Demerjian [8,9] to measure managerial ability. This method is measured based on the company's efficiency and cannot be performed by other managers. Third, this study did not take into account the variables that managerial ability and compensation could affect firm value. For example, corporate governance structure [47] and corporate social responsibility activities [35] can be important factors in which managerial ability or compensation has a differentiating effect on firm value.

Therefore, in the future, in order to study the relationship between executive compensation and firm value, the problem of stock compensation measurement should be considered. In addition, we used the research method of Demerjian et al. [8,9] for managerial abilities. Demerjian et al. [8,9] based managerial abilities on efficiency. However, managerial skills need to be considered in many ways. Future research suggests that it is necessary to develop various measurements of managerial ability.

Nevertheless, we can analyze the moderating effect of managerial ability for the inconsistent cause of executive compensation and firm value. In addition, there is a lack of research that has been limited to small and medium-sized enterprises (SMEs) in previous studies in this field. This study suggests that the importance of managerial ability among the managerial characteristics of SMEs is an essential factor that can affect the value, sustainability, and growth.

Author Contributions: Conceptualization, W.P. and C.B.; methodology, W.P.; software, W.P.; validation, W.P. and C.B.; formal analysis, W.P. investigation, C.B.; resources, W.P.; data curation, W.P.; writing—original draft preparation, W.P.; writing—review and editing, C.B.; visualization, C.B.; supervision; project administration, C.B.; funding acquisition, W.P. All authors have read and agreed to the published version of the manuscript.

Funding: This research received no external funding.

Institutional Review Board Statement: Not applicable. 
Informed Consent Statement: Not applicable.

Data Availability Statement: We collected financial and stock price data from KIS-VALUE by NICE Information Service Company and TS-2000 by Korea Listed Companies Association for executive compensation data.

Conflicts of Interest: The authors declare no conflict of interest.

\section{References}

1. Kim, A.; Jo, M. An Empirical study on the replacement of the chief executive officer of a owned management company: Comparison of ownership and professional management professionals. Strateg. Manag. Res. 2011, 14, 57-75.

2. Ko, C.; Park, J.; Jung, H.; Yoo, G. A Study on the influence of management capacity using DEA on corporate performance. Manag. Account. Study 2013, 13, 165-200.

3. Andreou, P.C.; Ehrlich, D.; Louca, C. Managerial Ability and Firm Performance: Evidence from the Global Financial Crisis; Working Paper; Cyprus University of Technology: Limassol, Greek, 2013; pp. 1-40.

4. Francis, J.; Nanda, D.; Olsson, P. Voluntary disclosure, earnings quality, and cost of capital. J. Account. Res. 2008, 46, 53-99. [CrossRef]

5. Katz, S.P.; Khan, U.; Schmidt, A. Tax avoidance and future profitability. In Columbia Business School Research Paper; SSRN: New York, NY, USA, 2013; Volume 10-13, pp. 1-54.

6. Graham, J.R.; Li, S.; Qiu, J. Managerial attributes and executive compensation. Rev. Financ. Stud. 2012, 25, 144-186. [CrossRef]

7. Koester, A.; Shevlin, T.; Wangerin, D. The role of managerial ability in corporate tax avoidance. Manag. Sci. 2016, 63, 3285-3310. [CrossRef]

8. Demerjian, P.; Lev, B.; McVay, S. Quantifying managerial ability: A new measure and validity tests. Manag. Sci. 2012, 58, 1229-1248. [CrossRef]

9. Demerjian, P.; Lev, B.; Lewis, M.; McVay, S. Managerial ability and earnings quality. Account. Rev. 2013, 88, 463-498. [CrossRef]

10. Rose, N.; Shepard, A. Firm diversification and CEO compensation: Managerial ability or executive entrenchment? RAND J. Econ. 1997, 28, 489-514. [CrossRef]

11. Park, I. Executive Compensation Program Related to Corporate Strategy; LG Economic Research Institute: Seoul, Korea, 2014.

12. Kim, H. Innovation strategy in personnel and pay systems for employment of the aged in Japanese enterprises. Korean-Jpn. J. Econ. Manag. Stud. 2003, 45, 3-43.

13. Kim, H.; Choi, S.; Kim, H. The Effect of corporate governance structure on tax avoidance. Korean Acad. Soc. Bus. Adm. 2014, 109, 3721-3744.

14. Kim, W.; Lee, E.; Kang, J. Executive Compensation and Performance Linkage Analysis (2013-2014), Report of Economic Reform; Economic Reform Research Institute: Seoul, Korea, 2015; pp. 1-34.

15. Said, A.A.; Hassab Elnaby, H.R.; Wier, B. An empirical investigation of the performance consequences of nonfinancial measures. J. Manag. Account. Res. 2003, 15, 193-223. [CrossRef]

16. Gilad, B.; Levine, P. A behavior model of entrepreneurial supply. J. Small Bus. Manag. 1986, 24, 45-53.

17. Gódány, Z.; Machová, R.; Mura, L.; Zsigmond, T. Entrepreneurship motivation in the 21st century in terms of pull and push factors. Technol. Educ. Manag. Inf. 2021, 10, 334-342.

18. Bertrand, M.; Schoar, A. Managing with style: The effect of managers on firm policies. Q. J. Econ. 2003, 118, 1169-1208. [CrossRef]

19. Cabaix, X.; Landier, A. Why has CEO pay increased so much? Q. J. Econ. 2008, 123, 49-100.

20. Kaplan, S.; Minton, B. How has CEO Turnover Changed? Increasingly Performance Sensitive Board and Increasingly Uneasy CEOs; Working Paper; NBER: Cambridge, MA, USA, 2006; pp. 1-35.

21. Oh, H.H. A Study on the Relationship Between Management Compensation and Enterprise Performance. Ph.D. Thesis, Chonbuk National University's Graduate School, Jeonju, Korea, 2011.

22. Charles, P.; Himmelberg, R.; Glenn, H. Investor, Protection, Ownership, and Investment; Working Paper; Columbia University: New York City, NY, USA, 2000; pp. 1-43.

23. Kaplan, S.; Rauh, J. Wall street: What contributes to the rise in the highest income? Rev. Financ. Stud. 2010, 23, 1004-1050. [CrossRef]

24. Lee, K.; Lee, S.; Park, A. Management stock option compensation and corporate value: Linear nonlinear system analysis. Manag. Stud. 2005, 34, 1637-1665.

25. Agarwal, N. Determinants of executive compensation. Ind. Relat. 1981, 20, 36-45. [CrossRef]

26. Gaver, J.; Gaver, M. Additional evidence on the association between the investment opportunity set and corporate financing, dividend, and compensation policies. J. Account. Econ. 1993, 16, 125-160. [CrossRef]

27. Finkelstein, S.; Hambrick, D.; Cannella, A.A. Strategic Leadership; West Educational Publishing: St. Paul, MN, USA, 1996.

28. Rajagopalan, N. Strategic orientations, incentive plan adoptions, and firm performance: Evidence from electric utility firms. Strateg. Manag. J. 1997, 18, 761-785. [CrossRef]

29. Murphy, K.J. Executive compensation: Where we are, and how we got there. In Chapter 4 of Handbook of the Economics of Finance; Elsevier: Los Angeles, CA, USA, 2013; Volume 2, pp. 211-356.

30. Jensen, M.C.; Murphy, K.J. Performance pay and top-management incentives. J. Political Econ. 1990, 98, 225-264. [CrossRef]

31. Song, D. An Empirical Study on the Relevance of Management Compensation, Corporate Governance and Management Risk. Ph.D. Thesis, Chonnam National University, Gwangju, Korea, 2014. 
32. Shin, H.; Chang, J. Firm performance following CEO turnover. Korean J. Financ. Assoc. 2003, 16, 231-256.

33. Choi, K.; Kim, H. CEOs forecasting ability and CEO compensation. Korean J. Manag. Account. Res. 2016, 16, 53-73.

34. Kartadjumena, E.; Rodgers, W. Executive compensation, sustainability, climate, environmental concerns, and company financial performance: Evidence from Indonesian commercial banks. Sustainability 2019, 11, 1673. [CrossRef]

35. Li, Z.; Thibodeau, C. CSR-contingent executive compensation incentive and earnings management. Sustainability $2019,11,3421$. [CrossRef]

36. Lee, M.; Hwang, I. The effect of the compensation system on earnings management and sustainability: Evidence from Korea banks. Sustainability 2019, 11, 3165. [CrossRef]

37. Lambert, R.A.; Larcker, D.F. An analysis of the use of accounting and market measures of performance in executive compensation contracts. J. Account. Res. 1987, 25, 85-125. [CrossRef]

38. Song, D.; Kim, Y. An empirical analysis of the relevance of management compensation, corporate governance, management risk, and corporate value. Financ. Eng. Res. 2018, 17, 133-159.

39. Lee, E. The Adjustment Effect of Profit Flexibility on the Relationship between Management Ability and Management Compensation. Ph.D. Thesis, Graduate School of Pusan National University, Busan, Korea, 2018.

40. Healy, P.M.; Walen, J.M. A review of the earnings management literature and its implications for standard setting. Account. Horiz. 1999, 13, 365-383. [CrossRef]

41. Healy, P.M. The effect of bonus schemes on accounting decisions. J. Account. Econ. 1985, 7, 85-107. [CrossRef]

42. Holthausen, C.; Rønde, T. Cooperation in International Banking Supervision; Working Paper; European Central Bank: Frankfurt, Germany, 2004; pp. 1-57.

43. Park, J.; Lee, D. A study on the management compensation and information non-alignment of accounting fraud intellectual enterprises. Account. Inform. Res. 2012, 30, 409-430.

44. Finkelstein, S.; Hamrick, D.C. Chief executive compensation: A study of the intersection of markets and political processes. Strateg. Manag. J. 1989, 10, 121-134. [CrossRef]

45. Lieberman, M.B.; Demeester, L. Inventory reduction and productivity growth: Linkages in the Japanese automotive industry. Manag. Sci. 1999, 45, 466-485. [CrossRef]

46. Baik, B.; Farber, D.B.; Lee, S. CEO ability and management earnings forecasts. Contemp. Account. Res. 2011, 28, 1645-1668. [CrossRef]

47. Park, S.; Jung, H. The effect of managerial ability on future stock price crash risk: Evidence from Korea. Sustainability 2017, 9, 2334. [CrossRef]

48. Wasserman, N.; Nohria, N.; Anand, B. When Does Leadership Matter? The Contingent Opportunities View of CEO Leadership. In Harvard Business School Working Paper; Harvard Business School: Boston, MA, USA, 2010; pp. 1-63.

49. Kang, S.; Kim, Y. The impact of management ability on long-term and short-term corporate performance in chaebol companies. Manag. Inf. Res. 2017, 36, 199-215.

50. Francis, B.B.; Hasan, I.; Wu, Q.; Yan, M. Are female CFOs less tax aggressive? Evidence from tax aggressiveness. J. Am. Tax. Assoc. 2014, 36, 171-202. [CrossRef]

51. Kwon, S. An Analysis of Tax Evasion and Business Characteristics. Master's Thesis, Kyungpook National University, Daegu, Korea, 2008.

52. Oh, D. The Relationship between the Value (Performance) of Foreign Investors and Korean Companies. Ph.D. Thesis, Korea University, Seoul, Korea, 2014.

53. Cho, Y. A study on dividend expenditure and future profit growth. In Proceedings of the Academic Conference of the Korean Financial Society, Seoul, Korea, 2 November 2007; pp. 1824-1838.

54. Gu, W. The effect of cash holding levels on management performance of food service companies. Tour. Leis. Res. 2019, 31, 259-275.

55. Ji, S.; Kim, T. An empirical study on the relationship between management compensation and accounting profit characteristics. Account. Res. 2001, 26, 25-56.

56. Choi, S.; Yang, S. Effect of management ability on actual profit adjustment using R\&D expenses. Account. J. 2019, $28,101-139$.

57. Byun, S.; Lee, E. CEO inside debt and earnings management. Korean Corp. Manag. Rev. 2013, 51, 25-41. [CrossRef]

58. Rosen, S. Authority, control, and the distribution of earnings. Bell J. Econ. 1982, 13, 311-323. [CrossRef]

59. DeAngelo, H.; DeAngelo, L.; Stulz, R.M. Seasoned equity offerings, market timing, and the corporate life cycle. J. Financ. Econ. 2010, 95, 275-295. [CrossRef]

60. Stein, J.C. Internal capital markets and the competition for corporate resources. J. Financ. 1997, 52, 111-133. [CrossRef]

61. Bushman, R.; Chen, Q.; Engel, E.; Smith, A. Financial accounting information, organizational complexity and corporate governance systems. J. Account. Econ. 2004, 37, 167-201. [CrossRef]

62. Ko, C. A Study on the Influence of Management Ability on Management Performance and Tax Evasion. Ph.D. Thesis, Hanyang University, Seoul, Korea, 2013.

63. Kim, Y.; Park, W. The impact of corporate life cycle and business strategy on future performance. Korean Int. Account. Rev. 2019, 83, 189-212.

64. Kim, T.; Choi, J. A Study on the relationship between export and business performance: To Korean manufacturing enterprises. Ind. Econ. Res. 2017, 30, 1779-1795.

65. Jang, J.; Kim, J. The characteristics of the CEO and the level of the company's cash reserves. Ind. Econ. Res. 2016, $29,1781-1813$. 